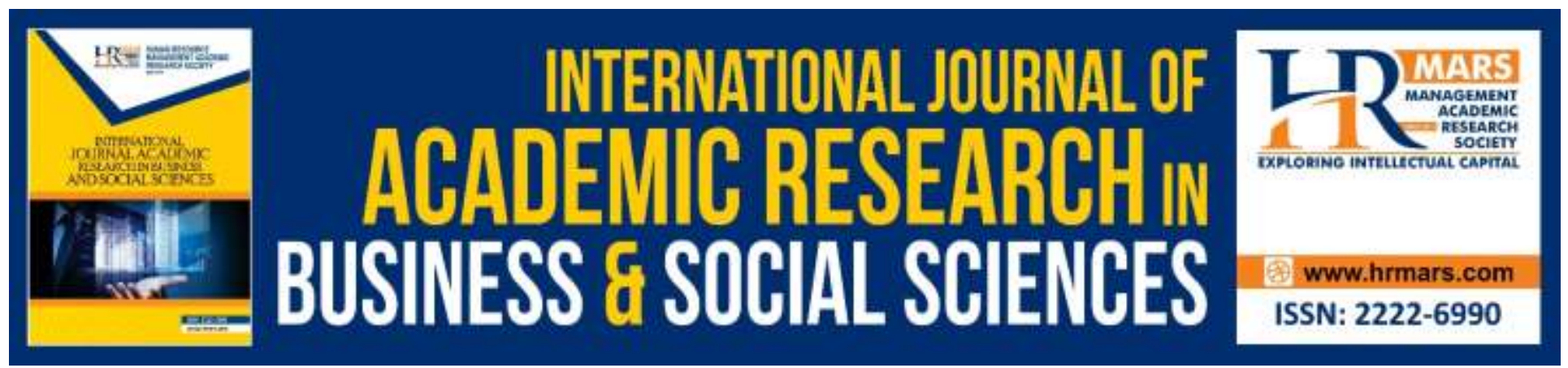

\title{
Relationship Between ICT Usage for Internal Communication and Principals' Administrative Quality in Public Secondary Schools in Homabay County
}

Obuoda Gilbert, Dawo Jane Irene and Sika James

To Link this Article: http://dx.doi.org/10.6007/IJARBSS/v10-i3/7098

DOI:10.6007/IJARBSS/v10-i3/7098

Received: 05 February 2020, Revised: 25 February 2020, Accepted: 16 March 2020

Published Online: 28 March 2020

In-Text Citation: (Gilbert et al., 2020)

To Cite this Article: Gilbert, O., Irene, D. J., \& James, S. (2020). Relationship Between Ict Usage For Internal Communication And Principals' Administrative Quality In Public Secondary Schools In Homabay County. International Journal of Academic Research in Business and Social Sciences, 10(3), 869-881.

Copyright: (C) 2020 The Author(s)

Published by Human Resource Management Academic Research Society (www.hrmars.com)

This article is published under the Creative Commons Attribution (CC BY 4.0) license. Anyone may reproduce, distribute, translate and create derivative works of this article (for both commercial and non-commercial purposes), subject to full attribution to the original publication and authors. The full terms of this license may be seen at: http://creativecommons.org/licences/by/4.0/legalcode

Vol. 10, No. 3, 2020, Pg. 809 - 881

Full Terms \& Conditions of access and use can be found at http://hrmars.com/index.php/pages/detail/publication-ethics 


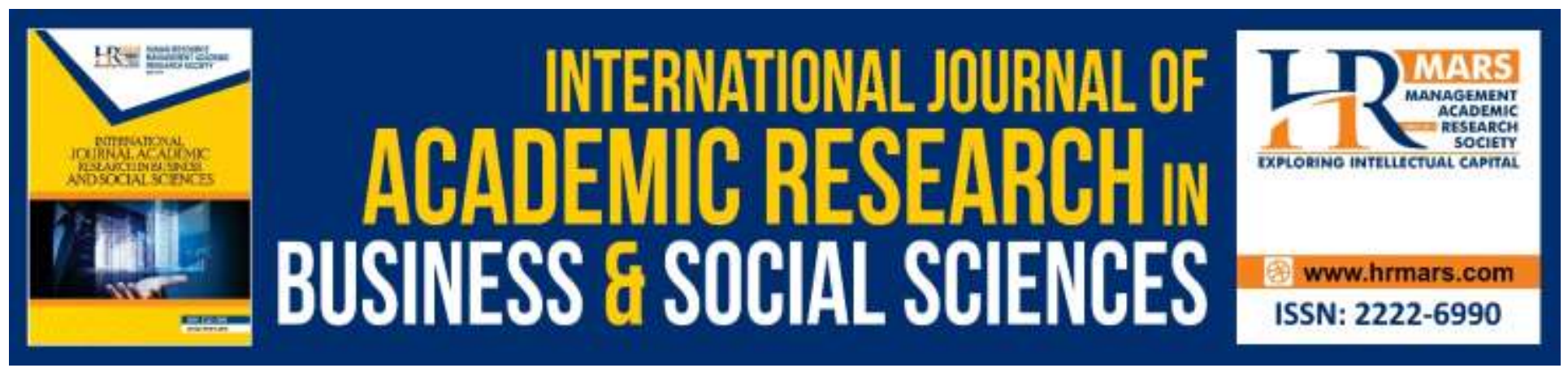

\title{
Relationship Between ICT Usage for Internal Communication and Principals' Administrative Quality in Public Secondary Schools in Homabay County
}

\author{
Obuoda Gilbert, Dawo Jane Irene and Sika James \\ Maseno University, Department of Education Management and Foundations, P.O.Box 333, \\ Maseno, Kenya. \\ Email: dawojanei@gmail.com
}

\begin{abstract}
Education sub-sector in Kenya has embraced Information Communication Technology (ICT) entrenchment in school management with the expectation of value addition, hence optimized organizational outcomes. Studies in various counties in Kenya on effect of ICT entrenchment in individual subjects reveal improvement in subsequent KCSE means core in the period 2010-2015. However, in Homabay County, KCSE results from the period 2013 has fluctuated negatively dropping by a mean standard score of 2.4 by 2017 for ICT entrenched secondary schools. This was more than the drop of 1.2, 1.0, and 1.0 realized in neighboring Migori, Kisii, and Kisumu Counties respectively for such schools. Literature reveals weak human relations in ICT work environment and that managers may manipulate subordinates administratively through interpersonal human relations quality to positively alter organizational output. Given that ICT-tools do not operate devoid of human environment, the purpose of this study is to establish the relationship between ICT Usage and principals' administrative quality of public secondary schools in Homabay County. The objective of study were to determine the relationship between ICT-Usage in internal Communication and principals' administrative quality. The conceptual framework will be drawn from Socio-Technical Systems Theory (Von Bertalanffy,1968). The study employed descriptive and correlation research design. Population of the study consisted of 102 principals, deputy principals, ICT-Usage Teacher-incharge, and 1498 teachers. Saturated Sampling technique selected 91 principals, deputy principals, ICT-Usage teacher-in-charge, and Simple Random sampling for 310 teachers. Data collection instruments were questionnaire, document analysis, and interview schedule. Test-retest was used for piloting involving 11 principals, 11 deputy principals, 11 ICT-Usage teacher in-charge, and 20 teachers. Qualitative data was categorized thematically as they emerged while quantitative data was subjected to Pearson's Product Moment Correlation Coefficient ( $r$ ) and coefficient of 0.7 considered acceptable. The study findings shall be useful for generating information about the usage of ICT and ways in which it aids principals' administrative quality. The study found a strong positive correlation
\end{abstract}


INTERNATIONAL JOURNAL OF ACADEMIC RESEARCH IN BUSINESS AND SOCIAL SCIENCES

Vol. 10, No. 3, March, 2020, E-ISSN: 2222-6990 @ 2020 HRMARS

between ICT usage in internal communication and principal's administrative quality. The mobile phone was the most commonly used mode of ICT for internal communication. It therefore recommended enhanced ICT usage for increased principal's administrative quality.

Keywords: Information and Communication Technology (ICT), Internal Communication, Principal's Administrative Quality.

\section{Background to the Study}

Several Nations of the word have placed much importance on the use of ICT in the administrative affairs. For instance, e-filling has become the best solution in tax administration in Ghana (Baokye and Banini, 2007); web services and e-services enable the Revenue Department to provide successful e-services to public in England (Kennewell, Parkinson and Tanner, 2007). ICT has also shaped African schools and classrooms (Mbangwana, 2007); and ICT has brought about organizational change in Italian Manufacturing Firms during 1995-2003 (Giruri, Torris and Zinovyeva, 2008). A survey done by National Council for Education Technology (NCET) in 1994, involving a sample of 371 secondary schools in America indicated that $86 \%$ of the schools used IT to support a variety of administration, organizational and management tasks.

In the current globalized economy, a country requires an ICT- literate workforce that will enhance its participation in the knowledge economy. ICT education, therefore, is the natural platform for equipping the nations with ICT skills for dynamic and sustainable economic growth. Any country that fails to integrate ICT risks serious marginalization on the global scene. (MOEST Strategic Plan, 20062011). Raby (2004), in his study conducted in Uganda regarding utilization of ICT in administration of human resource revealed that in most secondary schools, it was the responsibility of the principals. In this respect, many schools in Kenya has embraced ICT in a bid to aligning themselves to the tone of several government policies with a view to enhancing organizational (KCSE) outcomes. These documents include Kenya vision 2030 (Republic of Kenya, 2008) and Economic recovery strategy for wealth and employment creation (Republic of Kenya,2003). However, despite evident ICTentrenchment in Homabay County Schools, KCSE results dropped by 2.4 while its neighbouring counties dropped by $1.2,1.0$ and 1.0 respectively for Migori, Kisii and Kisumu, indicating that ICTentrenchment in schools had worst effect in Homabay County, Kenya. Therefore it was important to investigate the relationship between ICT Usage and principals' administrative quality of public secondary schools in Homabay County.

\section{Hypothesis of the Problem}

$\mathbf{H}_{\mathbf{0 1}}$ There is no relationship between ICT usage in internal communication and principals' administrative quality in public secondary schools in Homabay County.

\section{Statement of the Problem}

Even though literature reveals weak human relations between bosses and subordinates in ICT entrenched environments. ICT entrenchment in management of institutions is expected to lead to optimized organizational outcomes. However, in Homabay County KCSE results of ICT entrenched public secondary schools over the year 2013 and 2017 indicated a drop of 2.4 in mean standard score that was greater than the drop indicated in Migori, Kisii, and Kisumu Counties, of 1.2, 1.0, and 1.0 respectively. In addition, comparatively non-ICT-entrenched secondary schools in Homabay had a 
drop-in performance that was less than the ICT entrenched, there by negating the expected value addition attached to ICT-entrenchment. KCSE result being the key indicator of wholesome quality of all activities in school setting, the comparatively drop in performance in Homabay County raises concern to education stakeholders. Due to this, it is important to consider the quality of principals' human characteristics as these administratively inspire the subordinates who handle the ICT tools in a school for a performance which remains unexplored. Being the manager, the principals directly interact by way of internal communication through, and with stakeholders, key among them, being teachers, Deputy Head teachers and ICT teachers. Therefore, this study seeks to investigate the relationship between ICT-Usage in internal communication and principals' administrative quality of public secondary schools in Homabay County.

\section{Literature Review}

In the context of education, ICT is seen as the combination of technologies for collecting, storing, processing, communicating, and delivery of information related to teaching and learning processes (Ubani \& Njoku, 2006). On the other hand, Onuma (2007) sees ICT in a broad term as harnessing of the process, the methods, and the products of electronic and communication-related technologies for enhancing the productivity, spread and efficiency of a set of programmed activities geared towards the achievement of clearly determined goals. Edem (2005) asserts that communication is the ingredient which makes administration of an organization possible. In this respect, Idowu (2005) posits that as teachers receive motivation to get things done in the school environment through the principals' good communication channel; so, would the principals be realizing the school organizational goals. Therefore, good communication aids attainment of a quality administrative system.

\section{Results and Discussion}

\section{ICT Usage in Internal Communication in Public Secondary Schools}

In exploring the views of respondents (Deputy Headteachers and ICT teachers), a Likert scale itemized questionnaire was used. The items of the questionnaire were indicators of use ICT usage in internal communication. The responses were scored using a four-point continuum scale depending on how many strongly agree (4 points), agree (3 points), disagree ( 2 points) and strongly disagree (1 point). The scores were summated to measure the respondents' attitude on the use of ICT usage in internal communication in their schools. ICT teachers and Deputy Headteachers were considered suitable in gauging internal communication due to their critical positioning in ICT administration in a school. Their views were summarized in percentage frequencies as shown in Table 1 and Table 2. In this respect, Table 1 shows opinions from Deputy Headteachers on ICT usage. 
INTERNATIONAL JOURNAL OF ACADEMIC RESEARCH IN BUSINESS AND SOCIAL SCIENCES

Vol. 10, No. 3, March, 2020, E-ISSN: 2222-6990 @ 2020 HRMARS

Table 1: Deputy Headteacher Responses on ICT Usage in Internal School Communication Management in Secondary Schools in Homabay County $(\mathrm{N}=81)$

\begin{tabular}{|c|c|c|c|c|c|c|c|}
\hline $\begin{array}{l}\text { Comm. } \\
\text { Aspect }\end{array}$ & Respondents & 1 & 2 & 3 & 4 & Mean & SD \\
\hline $\begin{array}{l}\text { Digital } \\
\text { projector }\end{array}$ & DHT & $\begin{array}{l}40 \\
(49.4 \%)\end{array}$ & $\begin{array}{l}31 \\
138.3 \%\end{array}$ & $\begin{array}{l}10 \\
(12.3 \%)\end{array}$ & $0(0.0 \%)$ & 2.63 & 1.02 \\
\hline Video & DHT & $\begin{array}{l}42 \\
(51.9 \%)\end{array}$ & $\begin{array}{l}29 \\
(35.8 \%)\end{array}$ & 9 (11.1\%) & $1(1.2 \%)$ & 2.83 & 1.04 \\
\hline Email & DHT & $\begin{array}{l}28 \\
(34.6 \%)\end{array}$ & $\begin{array}{l}27 \\
(33.3 \%)\end{array}$ & $\begin{array}{l}18 \\
(22.2 \%)\end{array}$ & $8(9.9 \%)$ & 3.43 & 0.80 \\
\hline SMS & DHT & $\begin{array}{l}67 \\
(82.7 \%)\end{array}$ & $\begin{array}{l}11 \\
(13.6 \%)\end{array}$ & $2(2.5 \%)$ & $1(1.2 \%)$ & 3.68 & 0.67 \\
\hline Twitter & DHT & $\begin{array}{l}21 \\
(25.9 \%)\end{array}$ & $\begin{array}{l}28 \\
(34.6 \%)\end{array}$ & $\begin{array}{l}12 \\
(14.8 \%)\end{array}$ & $\begin{array}{l}20 \\
(24.7 \%)\end{array}$ & 2.22 & 1.02 \\
\hline $\begin{array}{l}\text { What's } \\
\text { App }\end{array}$ & DHT & $\begin{array}{l}59 \\
(72.8 \%)\end{array}$ & $\begin{array}{l}19 \\
(23.5 \%)\end{array}$ & $1(1.2 \%)$ & $2(2.5 \%)$ & 3.54 & 0.76 \\
\hline Radio & DHT & $\begin{array}{l}42 \\
(51.9 \%)\end{array}$ & $\begin{array}{l}27 \\
(33.3 \%)\end{array}$ & $\begin{array}{l}10 \\
(12.3 \%)\end{array}$ & $2(2.5 \%)$ & 2.44 & 1.21 \\
\hline TV & DHT & $\begin{array}{l}53 \\
(65.4 \%)\end{array}$ & $\begin{array}{l}23 \\
(28.4 \%)\end{array}$ & 4 (4.9\%) & $1(1.2 \%)$ & 2.92 & 1.24 \\
\hline FAX & DHT & $\begin{array}{l}18 \\
(22.2 \%)\end{array}$ & $\begin{array}{l}20 \\
(24.7 \%)\end{array}$ & $\begin{array}{l}22 \\
(27.2 \%)\end{array}$ & $\begin{array}{l}21 \\
(25.9 \%)\end{array}$ & 2.01 & 1.01 \\
\hline $\begin{array}{l}\text { Mobile } \\
\text { phones/ } \\
\text { Telephone }\end{array}$ & DHT & $\begin{array}{l}63 \\
(77.8 \%)\end{array}$ & $\begin{array}{l}17 \\
(21.0 \%)\end{array}$ & $1(1.2 \%)$ & $0(0.0 \%)$ & 3.86 & 0.43 \\
\hline $\begin{array}{l}\text { Digital } \\
\text { printer/ } \\
\text { Scanner }\end{array}$ & DHT & $\begin{array}{l}49 \\
(60.5 \%)\end{array}$ & $\begin{array}{l}26 \\
(32.1 \%)\end{array}$ & 4 (4.9\%) & $2(2.5 \%)$ & 3.62 & 0.72 \\
\hline Instagram & DHT & $\begin{array}{l}19 \\
(23.5 \%)\end{array}$ & $\begin{array}{l}13 \\
(16.0 \%)\end{array}$ & $\begin{array}{l}19 \\
(23.5 \%)\end{array}$ & $\begin{array}{l}30 \\
(37.0 \%)\end{array}$ & 1.95 & 1.06 \\
\hline Average & & & & & & 3.01 & 0.92 \\
\hline
\end{tabular}

Key: 4- Strongly agree, 3- Agree, 2- Disagree, 1- Strongly disagree

Source: Survey data (2019)

Interpretation: 1-1.4- Minimal usage; 1.5-2.4-Satisfactory usage; 2.5-3.4- Regular usage; 3.5-4.0Common usage.

DHT: Deputy Headteacher

The findings of the study established that ,according to Deputy Headteachers, generally ICT is regularly used in the management of internal communication process and procedures in many of the schools within the county. This was reflected by a mean rating of 3.01 with standard deviation of 0.92 in the scale of 1-4. This finding implies only a moderate level of entrenchment of computer application in internal communication management. 
INTERNATIONAL JOURNAL OF ACADEMIC RESEARCH IN BUSINESS AND SOCIAL SCIENCES

Vol. 10, No. 3, March, 2020, E-ISSN: 2222-6990 @ 2020 HRMARS

Following is Table 2 which shows the opinion of ICT teachers on school internal communication.

Table 2: ICT Teacher Responses on ICT Usage in Internal School Communication Management in Secondary Schools in Homabay County

\begin{tabular}{|c|c|c|c|c|c|c|c|}
\hline $\begin{array}{l}\text { Comm. } \\
\text { Aspect }\end{array}$ & Respondents & 1 & 2 & 3 & 4 & Mean & SD \\
\hline $\begin{array}{l}\text { Digital } \\
\text { projector }\end{array}$ & ICT TR & $\begin{array}{l}18 \\
(20.7 \%)\end{array}$ & $\begin{array}{l}35 \\
(41.4 \%)\end{array}$ & $\begin{array}{l}16 \\
(18.4 \%)\end{array}$ & $\begin{array}{l}17 \\
(19.5 \%)\end{array}$ & 3.37 & 0.69 \\
\hline Video & ICT TR & $\begin{array}{l}29 \\
(33.3 \%)\end{array}$ & $\begin{array}{l}26 \\
(29.9 \%)\end{array}$ & $\begin{array}{l}20 \\
(23.0 \%)\end{array}$ & $\begin{array}{l}12 \\
(13.8 \%)\end{array}$ & 3.38 & 0.98 \\
\hline Email & ICT TR & $\begin{array}{l}50 \\
(57.5 \%)\end{array}$ & $\begin{array}{l}28 \\
(32.2 \%)\end{array}$ & $5(5.7 \%)$ & $4(4.6 \%)$ & 2.93 & 0.98 \\
\hline SMS & ICT TR & $\begin{array}{l}68 \\
(78.2 \%)\end{array}$ & $\begin{array}{l}11 \\
(12.6 \%)\end{array}$ & $7(8.0 \%)$ & $1(1.1 \%)$ & 3.78 & 0.54 \\
\hline Twitter & ICT TR & $9(10.3 \%)$ & $\begin{array}{l}30 \\
(34.5 \%)\end{array}$ & $\begin{array}{l}19 \\
(21.8 \%)\end{array}$ & $29(33.3 \%)$ & 2.62 & 1.12 \\
\hline $\begin{array}{l}\text { Whats } \\
\text { App }\end{array}$ & ICT TR & $\begin{array}{l}58 \\
(66.7 \%)\end{array}$ & $\begin{array}{l}21 \\
(24.1 \%)\end{array}$ & $5(5.7 \%)$ & $1(3.4 \%)$ & 3.67 & 0.63 \\
\hline Radio & ICT TR & $\begin{array}{l}23 \\
(26.4 \%)\end{array}$ & $\begin{array}{l}22 \\
(25.3 \%)\end{array}$ & $\begin{array}{l}12 \\
(13.8 \%)\end{array}$ & $29(34.5 \%)$ & 3.35 & 0.79 \\
\hline TV & ICT TR & $\begin{array}{l}41 \\
(47.1 \%)\end{array}$ & $\begin{array}{l}21 \\
(24.1 \%)\end{array}$ & $2(2.3 \%)$ & $\begin{array}{l}23 \\
(26.4 \%)\end{array}$ & 3.58 & 0.65 \\
\hline FAX & ICT TR & $7(8.0 \% 0$ & $\begin{array}{l}24 \\
(27.6 \%)\end{array}$ & $\begin{array}{l}19 \\
(21.8 \%)\end{array}$ & $\begin{array}{l}37 \\
(42.5 \%)\end{array}$ & 2.43 & 1.10 \\
\hline $\begin{array}{l}\text { Mobile } \\
\text { phonecall } \\
\text { Telephone }\end{array}$ & ICT TR & $\begin{array}{l}78 \\
(89.7 \%)\end{array}$ & $6(6.9 \%)$ & $3(3.4 \%)$ & $0(0.0 \%)$ & 3.77 & 0.45 \\
\hline $\begin{array}{l}\text { Digital } \\
\text { printer/ } \\
\text { Scanner }\end{array}$ & ICT TR & $\begin{array}{l}63 \\
(72.4 \%)\end{array}$ & $\begin{array}{l}18 \\
(20.7 \%)\end{array}$ & $3(3.4 \%)$ & $1(3.4 \%)$ & 3.51 & 0.70 \\
\hline Instagram & ICT TR & 9 (10.3\%) & $\begin{array}{l}20 \\
(23.0 \%)\end{array}$ & $\begin{array}{l}16 \\
(18.4 \%)\end{array}$ & $\begin{array}{l}42 \\
(48.3 \%)\end{array}$ & 2.26 & 1.18 \\
\hline Average & & & & & & 3.22 & 0.80 \\
\hline
\end{tabular}

Key: 4- Strongly agree, 3- Agree, 2- Disagree, 1- Strongly disagree

Source: Survey data (2019)

Interpretation: 1-1.4- Minimal usage; 1.5-2.4-Satisfactory usage; 2.5-3.4- Regular usage; 3.5-4.0Common usage.

ICT TR: ICT and computers in-charge teacher in a school (ICT teacher)

The findings of the study in Table 2 established that, according to school computer-in-charge teachers, generally ICT is regularly used in the management of internal communication process and procedures in many of the schools within the county. This was reflected by a mean rating of 3.22 with standard deviation of 0.80 in the scale of 1-4. This finding implies a moderate level of entrenchment 
INTERNATIONAL JOURNAL OF ACADEMIC RESEARCH IN BUSINESS AND SOCIAL SCIENCES Vol. 10, No. 3, March, 2020, E-ISSN: 2222-6990 @ 2020 HRMARS

of computer application in internal communication management of schools. therefore, it can be concluded that ICT teachers (Table1)and Deputy Headteachers (Table2) are in agreement.

In this regard, research findings reveal that there is variance in application of ICT in different aspects of internal communication. For instance, mobile phones/telephone as a form of communication was rated highest by both categories of respondents with a mean of $3.86(S D=0.43)$ and $3.77(S D=0.45)$ by Deputy Headteachers and the ICT in-charge teachers respectively. Following were the use of the short message service (SMS) and Whats App in school internal communication management. A significant majority of the respondents, equivalent to 67 (82.7\%) of the Deputy Headteachers and 68 (78.2\%) of the ICT in-charge teachers, confirmed that SMS is always used as a form of communication in their schools. This was further corroborated during interview whereby 18 (90\%) Deputy Headteachers and $16(80 \%)$ ICT in-charge teachers, 20 (100\%) headteachers agreed that, apart from direct face to face verbal communication, SMS and Whats App are the most common form of internal communication. This was reflected by high mean ratings of $3.68(S D=0.67)$ and $3.78(S D=0.54)$ by the Deputy Headteachers and ICT teachers respectively. Equally, 59 (72.8\%) and 58 (66.7\%) of the Deputy Headteachers and ICT teachers respectively confirmed that WhatsApp is always a means of internal communication in their schools. On the same note, a significant majority, $49(60.5 \%)$ of the Deputy Headteachers and $63(72.4 \%)$ of ICT teachers confirmed that they always use digital printers in their school. This was verified by a mean rating of 3.62 (SD =0.72) and 3.51 (SD=0.70) by Deputy Headteachers and ICT teachers in secondary schools within Homabay County, Kenya.

As concerns some aspects of internal communication management, specifically, video, e-mail and television, the following were the findings: video had a mean rating of $2.83(\mathrm{SD}=1.04)$ by Deputy Headteachers and 3.38 ( $S D=0.98$ ) by ICT teachers indicating that they are regularly used for internal communication purposes in Homabay County secondary schools. Interview revealed that 10(50\%) ICT teachers just like 10(50\%) principals and 6(30\%) teachers identified video as an item that was sometimes used to pass critical management information such as on issues of punctuality, health and hygiene, teacher etiquette, and teaching skill upgrades. In addition, whereas 50 (57.5\%) of the ICT teachers confirmed that e-mail is used as a form of communication in their schools but only 28 (34.6\%) of the Deputy Headteachers agreed. A mean rating of 2.93 (SD=0.98) in a scale of 1-4 for ICT teachers reflects regular usage.

Most of the Deputy Headteachers, 15 (75\%) said by interview that they always use television for internal communication purposes in their schools which seems true given the mean of 3.59 (SD= 0.65). This they do by strategic reference to teachers as regards topical ideas that are displayed or focused through documentaries or news bulletin. Likewise, a mean rating of 2.92 (1.24) from the ICT teachers with $41(47.1 \%)$ of them indicating agreement, reflects that generally television is applied in internal communication uses in their schools through refereed television programmes by their principals or Deputy Headteachers. Some 11(55\%) headteachers explained that a modern day manager cannot do without himself watching or referring his staff to topical matters in strategic television documentaries.

Seemingly, of minimal usage is radio. This was supported by interview whereby $2(10 \%)$ teachers who said that they only listened to radios in public transport (matatus) and $1(5 \%)$ headteacher who said he could not remember the last time he listened to a radio. In addition, many of the ICT teachers denied use of Radio as a form internal communication in their schools, as shown by their mean rating of 2.44 ( $S D=1.21$ ) with only $23(26.4 \%)$ of them agreeing to its use in the Likert Scale. The foregoing 
INTERNATIONAL JOURNAL OF ACADEMIC RESEARCH IN BUSINESS AND SOCIAL SCIENCES Vol. 10, No. 3, March, 2020, E-ISSN: 2222-6990 @ 2020 HRMARS

indicate that radio is rarely used as a form of internal communication in secondary schools in Homabay County. Also rare is the use of digital projectors with a mean rating of $3.37(S D=0.69)$ by Deputy Headteachers and $2.63(\mathrm{SD}=1.02)$ by the ICT teachers. Moreover, less than half of the respondent $49.4 \%$ Deputy Headteachers and $20.7 \%$ of the ICT teachers said that they used digitals projectors for internal communication in their schools.

Research findings revealed that Instagram, fax and twitter are rarely used in internal communication management in secondary schools in Homabay County. These forms of internal communication registered very low mean ratings with twitter having $2.62(S D=1.12)$ and $2.22(S D=1.02)$ by Deputy Headteachers and ICT teachers, respectively. Use of fax in schools was rated at $2.43(S D=1.10)$ and $2.01(S D=1.01)$ by the Deputy Headteachers and ICT teachers, respectively. Equally, use of twitter as a form of internal communication only received a rating of $2.26(S D=1.18)$ and $1.95(S D=1.06)$ by the Deputy Headteachers and ICT teachers, respectively, with majority of them accepting that use of twitter as a form of internal communication. Evidence of email sent to select teachers on administrative matters by school principal and deputy headteacher, particularly when away from school compound on school-related responsibilities, were availed for perusal. One such e-mail document availed was copied to a Sub-county Education Officer, a school principal and a teacher in respect of a school bus that had developed technical problems and hence was to be packed overnight at a scene of breakdown neighbourhood school, and alternative transport, back to school, that had been arranged for the affected students.

The dependent variable, principal's administrative quality, was gauged from teachers' perspective (Table 3) since ordinarily, they interact more than other stakeholders with the school principal.

Table 3. Teacher Responses on Principal's Administrative Quality in Secondary Schools in Homabay County ( $\mathrm{N}=300)$

\begin{tabular}{|c|c|c|c|c|c|c|}
\hline Admin. Quality & 1 & 2 & 3 & 4 & Mean & SD \\
\hline Consultative & $225(75 \%)$ & $45(15 \%)$ & $30(10 \%)$ & $0(0.0 \%)$ & 1.35 & 0.79 \\
\hline Delegative & $162(54 \%)$ & $99(33 \%)$ & $39(13 \%)$ & $0(0.0 \%)$ & 1.59 & 0.74 \\
\hline Available & $135(45 \%)$ & $126(42 \%)$ & $39(12 \%)$ & $0(0.0 \%)$ & 1.68 & 0.78 \\
\hline Assertive/Focused & $189(63 \%)$ & $90(30 \%)$ & $21(7 \%)$ & $0(0.0 \%)$ & 1.44 & 0.63 \\
\hline $\begin{array}{l}\text { Approachable/ } \\
\text { accessible }\end{array}$ & $159(53 \%)$ & $120(40 \%)$ & $21(7 \%)$ & $0(0.0 \%)$ & 1.54 & 0.82 \\
\hline Visible & $159(53 \%)$ & $87(29 \%)$ & $48(16 \%)$ & $6(2 \%)$ & 1.67 & 0.80 \\
\hline $\begin{array}{l}\text { Knowledgeable/ } \\
\text { Dependable }\end{array}$ & $183(61 \%)$ & $84(28 \%)$ & $33(11 \%)$ & $0(0.0 \%)$ & 1.53 & 0.65 \\
\hline $\begin{array}{l}\text { Objective/ Open } \\
\text { minded }\end{array}$ & $153(51 \%)$ & $114(38 \%)$ & $27(9 \%)$ & $6(2 \%)$ & 1.62 & 0.69 \\
\hline Average & & & & & 1.55 & 0.69 \\
\hline
\end{tabular}

Key: 4- Strongly agree, 3- Agree, 2- Disagree, 1- Strongly disagree Source: Survey data (2019)

Interpretation: 1-1.4- Minimal compliance; 1.5-2.4-Satisfactory compliance; 2.5-3.4- Regular compliance; 3.5-4.0- Common compliance. 
Table 3 reveals that at a mean rating of 1.55, headteacher administrative quality from the teachers' point of view is satisfactorily compliant given that in all aspects majority of them strongly disagree with the stated positive human characteristics that are necessary for quality administration listed in the Likert scale. In respect of the ICT usage, when asked to write in order of prevalence the mode of internal communication used to pass information to them by school administration, $161(80.5 \%)$ and 39(19.5\%) respondent teachers identified mobile phone calls and Short Message Services(SMS) respectively first. This was confirmed when 30(100\%) teachers interviewed explained that the mobile phone was the most important ICT tool of internal communication. Interview of both 20(100\%) headteachers and 20(100\%) teachers revealed that $100 \%$ of them preferred mobile phone communication as it allowed clarification of matters and one was also able to, with near certainty, gauge the mood of the speaker. This was in agreement with Dawo (2016) in investigating how teacher workload management influenced their intention to transfer and found that how information was communicated determined how teachers perceived their work. This was also the same as in headteacher supervising teacher job performance (Dawo, Kawasonga \& Gogo, 2015).

\section{Analysis of Relationship between Variables}

The study is founded on the hypothesis that there is no relationship between ICT usage in internal communication and principals' administrative quality in public secondary schools in Homabay County.

To investigate whether there was any statistically significant relationship between ICT usage in internal communication and principals' administrative quality in public secondary schools in Homabay County, the null hypothesis was tested. Parametric tests, Pearson Moment Coefficient and regression analysis were conducted, with scores on ICT usage in internal communication as the independent variable and principals' administrative quality as the dependent variable. The level of ICT usage in internal communication and principals' administrative quality were computed from frequency of responses. Mean response across a set of questions of Likert scale responses in each item was computed to create an approximately continuous variable but within an open interval of 1 to 4, that is suitable for the use of parametric data, as explained by Johnson \& Creech (1983) and Sullivan \& Artino (2013), where high scale ratings implied high perceived ICT usage in internal communication and principals' administrative quality in public secondary schools. The significant level ( $p$-value) was set at .05, such that if the $p$-value was less than 0.05 , the null hypothesis would be rejected and conclusion reached that a significant difference exist. If the $p$-value was larger than 0.05 , it would be concluded that a significant difference does not exists. Table 4 shows the correlation analysis results to give a general position from Deputy Headteachers and ICT teachers on ICT usage on the said relationship with principal's administrative quality as revealed from teacher responses. Noteworthy is the fact that despite holding different positions in management, these 2 teaching personnel interact with the principal, almost always together, directly in ICT administration hence together they can give an objective report. 
INTERNATIONAL JOURNAL OF ACADEMIC RESEARCH IN BUSINESS AND SOCIAL SCIENCES Vol. 10, No. 3, March, 2020, E-ISSN: 2222-6990 C 2020 HRMARS

Table 4: Relationship between ICT Usage in Internal Communication and Principals' Administrative Quality

\begin{tabular}{|ll|r|r|}
\hline & $\begin{array}{c}\text { School Internal } \\
\text { Communication } \\
\text { Management }\end{array}$ & $\begin{array}{c}\text { Principals' } \\
\text { Administrative } \\
\text { Quality }\end{array}$ \\
\hline School Internal & Pearson Correlation & 1 & $.418^{* *}$ \\
Communication & Sig. (2-tailed) & 181 & .000 \\
Management & $\mathrm{N}$ & $.418^{* *}$ & 168 \\
& Pearson Correlation & .000 & 1 \\
Principals' & Sig. (2-tailed) & 181 & 181 \\
Administrative Quality & $\mathrm{N}$ & & \\
& &
\end{tabular}

**. Correlation is significant at the 0.01 level (2-tailed).

The finding of the study shows that there was statistically significant positive correlation between ICT usage in internal communication and principals' administrative quality in public secondary schools $(r=.418 ; p<.05)$. Given that the relationship is statistically significant, the hypothesis that, "there is no statistically significant relationship between ICT usage in internal communication and principals' administrative quality in public secondary schools in Homabay County" was therefore rejected. Hence, it concluded that there is statistically significant relationship between ICT usage in internal communication and principals' administrative quality in public secondary schools in Homabay County, with high level of ICT usage in internal communication associated to principals' administrative quality in public secondary schools and vice-versa.

However, to estimate the level of influence of ICT usage in internal communication on principals' administrative quality in public secondary schools, a coefficient of determination was computed using of regression analysis and the result was as shown in Table 5.

Table 5: Model Summary on Regression Analysis of Influence of ICT Usage in Internal Communication and Principals' Administrative Quality

\begin{tabular}{|c|c|c|c|c|}
\hline Model & $\mathrm{R}$ & $\mathrm{R}$ Square & Adjusted R Square & $\begin{array}{c}\text { Std. Error of the } \\
\text { Estimate }\end{array}$ \\
\hline 1 & $.418^{\mathrm{a}}$ & .175 & .170 & .37406 \\
\hline
\end{tabular}

a. Predictors: (Constant), School Internal Communication Management

b. Dependent Variable: Principals' Administrative Quality

The model summary reveals that ICT usage in internal communication accounted for $17.0 \%$, as signified by coefficient Adjusted $\mathrm{R}^{2}=.170$, of the variation in principals' administrative quality in public secondary schools. This finding implies that variation in the level of ICT usage in internal communication explains $17 \%$ of the variability in a principals' administrative quality. This is fairly large influence on a dependent variable by one predictor, hence, it signifies the importance of ICT usage in internal communication on principals' administrative quality in public secondary schools. Further 
INTERNATIONAL JOURNAL OF ACADEMIC RESEARCH IN BUSINESS AND SOCIAL SCIENCES

Vol. 10, No. 3, March, 2020, E-ISSN: 2222-6990 C 2020 HRMARS

analysis as shown in Table 6 shows the coefficients values of regression model of the influence of ICT usage in internal communication and principals' administrative quality.

Table 6: Coefficients- Influence of ICT Usage in Internal Communication and Principals' Administrative Quality

\begin{tabular}{|c|c|c|c|c|c|c|c|}
\hline \multirow[t]{2}{*}{ Model } & \multicolumn{2}{|c|}{$\begin{array}{c}\text { Unstandardized } \\
\text { Coefficients }\end{array}$} & \multirow{2}{*}{$\begin{array}{c}\text { Standardized } \\
\text { Coefficients } \\
\text { Beta }\end{array}$} & \multirow[t]{2}{*}{$\mathrm{t}$} & \multirow[t]{2}{*}{ Sig. } & \multicolumn{2}{|c|}{$\begin{array}{c}95.0 \% \text { Confidence } \\
\text { Interval for B }\end{array}$} \\
\hline & B & $\begin{array}{l}\text { Std. } \\
\text { Error }\end{array}$ & & & & $\begin{array}{l}\text { Lower } \\
\text { Bound }\end{array}$ & $\begin{array}{l}\text { Upper } \\
\text { Bound }\end{array}$ \\
\hline (Constant) & 2.350 & .186 & & 12.663 & .000 & 1.983 & 2.716 \\
\hline $\begin{array}{l}\text { School Internal } \\
\text { Communication Management }\end{array}$ & .355 & .060 & .418 & 5.935 & .000 & .237 & .473 \\
\hline
\end{tabular}

a. Dependent Variable: Principals' Administrative Quality

$Y=\alpha+\beta x+\varepsilon$

Principals' Administrative Quality $=2.350+0.355 x+$ error term .

From the model it is evident that the slope coefficient for ICT usage in school internal communication management was .355, implying that principals' administrative quality improves by 0.355 units for each one unit increase in ICT usage in school internal communication management. Similarly, an improvement in ICT usage in school internal communication management by one standard deviation results to improvement of principals' administrative quality by .418 standard deviations.

However, to investigate whether ICT usage in internal communication was a significant predictor to principals' administrative quality in public secondary schools, Analysis of Variance was conducted, in line with the recommendation by Creswell (2014), as shown in Table 7.

Table 7: ANOVA- Influence of ICT Usage in Internal Communication on Principals' Administrative Quality in Public Secondary Schools

\begin{tabular}{|l|r|r|r|r|r|}
\hline Model & Sum of Squares & df & Mean Square & F & Sig. \\
\hline Regression & 4.929 & 1 & 4.929 & 35.228 & $.000^{b}$ \\
1 Residual & 23.227 & 181 & .140 & & \\
Total & 28.156 & 182 & & & \\
\hline
\end{tabular}

a. Dependent Variable: Principals' Administrative Quality

b. Predictors: (Constant), School Internal Communication Management

From the ANOVA output, it is evident that ICT usage in internal communication is a significant predicator to principals' administrative quality in public secondary schools, $F(1,181)=35.228, p=.000$ $<.05$; Adjusted $\mathrm{R}^{2}=.170$. Therefore, it was concluded that ICT usage in internal communication is a significant predictor to principals' administrative quality in public secondary schools. This implies that principals who highly incorporate ICT usage in internal communication is likely to record high administrative quality in public secondary schools and vice-versa. 
INTERNATIONAL JOURNAL OF ACADEMIC RESEARCH IN BUSINESS AND SOCIAL SCIENCES

Vol. 10, No. 3, March, 2020, E-ISSN: 2222-6990 @ 2020 HRMARS

\section{Conclusion}

It is concluded that there is statistically significant relationship between ICT usage in internal communication and principals' administrative quality in public secondary schools in Homabay County. The study found out that ICT usage in internal communication is a significant predictor to principals' administrative quality in public secondary schools and hence schools whereby there was high level of ICT usage in internal communication were associated to principals' administrative quality in public secondary schools and vice-versa.

\section{Recommendations}

School management should enhance ICT usage in internal communication to enhance principal's administrative quality.

\section{About the Authors}

Obuoda Gilbert is a researcher undertaking PhD in Educational Administration at Maseno University while Dawo Jane Irene (Dr) and Sika James (Dr) are lecturers in Educational Administration and Educational Planning and Economics, respectively, at Maseno University, Kenya.

\section{References}

Baokyee \& Banini. (2008). Teacher ICT readiness in Ghana, Republic of Ghana

Dawo, J. I. (2016). Relationship between Teacher Work-Place Conditions and Teacher Transfer Intention in Public Secondary Schools in Mbita and Suba Sub-Counties, Kenya. Unpublished Ph.D. Thesis. Maseno University.

Dawo-Okwiri, J. I., Kawasonga, M. A., \& Gogo, J. O. (2015). School Leadership as Determinant of Teacher Transfer Intention in Public Secondary Schools in Mbita and Suba Sub-counties, Kenya. IOSR Journal of Humanities and Social Science (IOSR-JHSS) vol. 20, Issue9.

Edem, E. A. (2005). Principals' personal characteristics and organizational effectiveness of secondary schools in Southern Senatorial District of Cross River State, Nigeria. Unpublished M.Ed. Thesis, University of Calabar, Calabar, Nigeria.

Giurri, P., Torris, S., \& Zinovyeva, N. (2008). ICT skills and Organizational Change: Evidence from Italian Manufacturing Firms. Chicago: Oxford University Press.

Idowu, M. B. (2006). Communication and Intuitional stability, Paper presented at the National Conference on Information and Communication Technology in service of Education. University of Nigeria. Nsukka, may 15-18.

Kennewell, S. Parkinson, J., \& Tanner, H. (2007). Developing the ICT Capable School. London Routledge Books, p. 11-15. Also available at: http://www.mht/google Books. [accessed in Oyo, Nigeria: 24 August 2009]

Mbangwana, M. A. (2007). "Introduction to ICT in Cameroon" in K. Toure, T.M.S. Technology and T. Karsenti (eds). ICT and Changing Mind sets in Education. Available at: http://www.Repenser. I'education.al'aid.TIC mht. [accessed in Oyo, Nigeria: 24 August 2009].

Onuma, N. (2007). Utilization of Information and communication technology in schools: Problems and Suggestions. in J. B. Babalola, G. O. Akapa, A. O. Ayemi and S. O. Adebeji(eds) Access, Equity and Quality Higher Education 487-496

Raby, B. J. W. (2004). Vows of poverty and the tax collector https://ssrn.com/abstract=629361 
INTERNATIONAL JOURNAL OF ACADEMIC RESEARCH IN BUSINESS AND SOCIAL SCIENCES

Vol. 10, No. 3, March, 2020, E-ISSN: 2222-6990 @ 2020 HRMARS

Republic of Kenya. (2003). Economic Recovery Strategy of Wealth and Employment Creation. Nairobi: Government press.

Ubani \& Njoku. (2006). ICT and Nigerian Teachers. Paper delivered at Teachers Registration Council of Nigeria (TRCN), National Workshop. Abuja: TRCN,17 ${ }^{\text {th }}-21^{\text {st }}$ October 2006. 